\title{
New silvicultural approaches for multipurpose management in beech forests
}

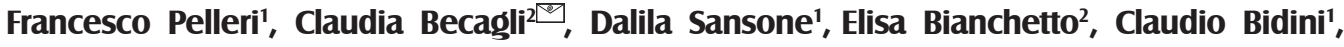 \\ Maria Chiara Manetti ${ }^{1}$
}

Pelleri F., Becagli C., Sansone D., Bianchetto E., Bidini C., Manetti M.C., 2021. New silvicultural approaches for multipurpose management in beech forests. Ann. For. Res. 64(2): 87-103.

Abstract Traditional thinning and stand silviculture had positive effects on tree stability, stand efficiency and tree growth if compared to the lack of management. Nevertheless, the tree oriented silviculture has proven to be a type of management best meets the multifunctionality pourpouses required by forests today. In Italy beech high forests are generally managed with traditional thinning from below ascribable to stand silviculture; in the last decades tree oriented silviculture, an innovative management system is spreading in Europe. The aim of the study is to compare two thinning types applied in two localities of central Italy, in beech stands deriving from shelterwood system, aged 45-50 years: stand silviculture (SS), treesilviculure (TS) and control (C). All trees were periodically measured in order to assess growth, mortality and production from 2008 onwards. Crop trees $\mathrm{DBH}$, selected for each silvicultural approach, was annually measured while, an evaluation of the stem quality, crown development and stability were carried out between the $1^{\text {st }}$ and last thinnings. Differences in vertical and horizontal diversity stand structures were assessed. Results pointed out similar growth rate at stand level; while a superior growth in diameter, in dimension of the crown and stability of the crop trees were observed in TS. The TS has proven to be the management option that best meets the multifunctionality required by forests today.

Keywords: beech, thinning, crop trees, silviculture, traditional silviculture, treeoriented silviculture.

Addresses: ${ }^{1}$ Consiglio per la ricerca in agricoltura e l'analisi dell'economia agraria (Council for Agricultural Research and Economics, Italy), Research Centre for Forestry and Wood (CREA-FL), Arezzo, Italy| ${ }^{2}$ Research Centre for Agriculture and Environment, Council for Agriculture Research and Economics, Firenze, Italy.

$\varpi$ Corresponding Author: Claudia Becagli (claudia.becagli@crea.gov.it).

Manuscript received June 01, 2021; revised October 29, 2021; accepted December 02, 2021. 


\section{Introduction}

Nowadays in Italy and in other European Countries some silvicultural systems oriented to irregular structures - such as Continuous Cover Forestry or Close-to-nature silviculture (Hahn \& Fanta 2001, Mason et al. 2003, Von Teuffel $\&$ Heim 2004, Brang et al. 2014) - are gaining in relevance, ensuring multifunctionality and guaranteeing forest-based goods and services.

These silvicultural approaches can provide higher ecosystem services compared to traditional ones based on "thinning from below" (higher aesthetical value, higher soil protection, larger assortment right from first thinning) and can contribute to increasing resilience levels and therefore combating climate change (Löf et al. 2015). The conversion from regular high forest to irregular high forest has to start in the pole stage or young high forest stage, applying frequent and moderate thinnings, able to focus the increment in a restricted number of crop trees. During an intervention the silviculturalist has to manage the quality of the stand, preserving and improving the growth of the crop trees, harvesting wolf and malformed trees, maintaining biodiversity and, at the same time, managing the understory layer and regeneration (Armand 2002).

A new silvicultural approach based on the selection of a small number of crop trees (treeoriented management system or tree-oriented silviculture) has been developed in recent decades in central Europe. This approach, developed in the $1^{\text {st }}$ half of the $20^{\text {th }}$ century, originated from the early selection of final crop trees (Michealis 1907, Ducellier 1930, Möller 1931), where the production of valuable timber - high quality and large-sized - is concentrated. This silvicultural approach has been further developed by other authors (De Saint-Vaulry 1969, Bastien 1997, Bastien \& Wilhelm 2000, Wilhelm 2003, Wilhelm \& Rieger 2017).

It differs from classical selective thinning, where a large number of candidates are chosen and favored in the young stand (pole stage) during the first thinning. In the following thinning the selection of the best candidates will be repeated until deciding on a final small number (Schädelin 1942, Schütz 1990, Boncina et al. 2007, Piussi \& Alberti 2015). In tree-oriented silviculture, since the first thinning, only a small number of crop trees (similar to the final density expected at the end of the rotation period) are selected.

This silvicultural system has been applied so far mainly to oak and beech high forests in central Europe and North America, in order to produce valuable timber of merchantable size in a shorter time at lower costs (Jobling \& Pearce 1977, Perkey et al. 1994, Perin \& Claessens 2009, De Potter et al. 2012), or to preserve and increase the presence of minor tree species both in mixed high forests and coppice stands (Spiecker 2006, Brunet et al. 2010, Sansone et al. 2012, Pelleri et al. 2013, Manetti et al. 2016, Manetti et al. 2020).

In this context, tree-oriented silviculture can be suitably applied both to manage, in a uniform way, even-aged beech forests, with a short regeneration period, or to manage irregular beech forests, diversifying in time the final cut of the crop trees, applying a long regeneration period.

In Italy this approach has been applied in Trentino and Piedmont in beech coppice stands converted into high forests (Wolynski et al. 2006, Wolynski 2002a, 2002b, Mairota et al. 2016, Negro et al. 2014).

Beech (Fagus sylvatica L.) represents one of the most important species in Italy, covering an area of 1,035,103 hectares. This tree species is characteristic in the mountain forests of the Alps and Apennines, and reaches the forest limit in most of the Apennine Mountain range. In Tuscany, according to the National Inventory of Forests and Forest Carbon Sinks (Tabacchi et al. 2007), there are 72,262 hectares of beech forests. These forests are managed as coppice (52\%), mainly coppice with a standard system, high forests $(16 \%)$ and coppice converted into high forests $(16 \%)$. Despite their mainly protective and tourist functions, beech forests 
also have played an important productive role, principally in firewood production. Coppicing for charcoal supply in local markets has been the major factor affecting forest structure (Cullotta et al. 2016, Coppini \& Hermanin 2007, Ciancio et al. 2006, Meyer et al. 2003). With falling demand for charcoal, most of the beech coppices were no longer managed, and many are currently being converted to high forests. Valuable timber production can be obtained only in some high forests and in coppices converted into high forests.

Generally, beech high forests are managed with a uniform shelterwood system and long rotation period (90-100 years), a regeneration period of about 20-30 years and the application of thinning from below starting at the age of 20-30 years (Nocentini 2009, Mariotti et al. 2017).

This study reports the results of the comparison between two different silvicultural management systems applied in beech forests: traditional silviculture and tree-oriented silviculture.

The goal of this study is to evaluate whether tree-oriented silviculture is able to produce more valuable and larger-sized assortments in comparison to traditional stand silviculture, and whether it favors the creation of multifunctional and irregular beech stands.

\section{Materials and Methods}

\section{Study areas}

The research was carried out in two important forest districts of Tuscany (Central Italy): Monte Amiata (Grosseto) and Abetone (Pistoia), areas covered by beech high forests managed in the past by intensive silviculture and by coppices converted into high forests.

Monte Amiata is an important area, near the Mediterranean Sea, characterized by a relevant presence of chestnut (Castanea sativa L.) and beech forests for wood production. The Amiata study area (coordinates 42,903064 $\mathrm{N}$ and 11,624496 E) is located at a height of
1,300 to $1,420 \mathrm{~m}$ a.s.l. on a trachyte bedrock. The most common soil is Andic Dystrudepts coarse loamy, siliceous, mesic (unit GUA1 - http://sit.lamma.rete.toscana.it/websuoli/), deep, soft, not gravelly, not calcareous, acidic, well drained. The climate is mountainMediterranean, with an annual rainfall of $1,547 \mathrm{~mm}$ mainly in the autumn and winter months, and a mean annual temperature of $10^{\circ} \mathrm{C}$. In this area two pure young high forest stands, $700 \mathrm{~m}$ from each other, originating from a shelterwood system, were selected: the Marsiliana stand (AM1), 45 years old, not thinned; the Pozzo Stella stand (AM2), 50 years old, characterized by a previous light thinning from below.

The Abetone district is a typical Apennine mountain area characterized by pure or mixed beech and silver fir (Abies alba Mill.) forests. The study area is located 1,200-1,270 m a.s.l. near the small village of Cecchetto (AB) on a sandstone bedrock. The most common soil is Humic Dystrudepts coarse loamy, mixed, mesic (unit MRS1 - http://sit.lamma.rete. toscana.it/ websuoli/) quite deep, non-gravel or gravelly, sandy loam, not calcareous, acidic, well drained. The climate is typical of the Apennine mountain, with an annual rainfall of $2,447 \mathrm{~mm}$ concentrated in the autumn and winter months, with a mean annual temperature of $6.6^{\circ} \mathrm{C}$. In this area, originating from a shelterwood system, one pure high forest stand, 50 years old (coordinates: 44,124382 $\mathrm{N}$ and 10,702399 E), was selected.

\section{Experimental silvicultural treatments}

Two silvicultural approaches were tested in the study areas. Traditional silviculture, characterized by low thinning of medium intensity, and tree-oriented silviculture, which some authors break down into five main points (Bastien \& Wilhelm 2000, Bastien et al. 2005, Wilhelm \& Rieger 2017, Kerr \& Haufe 2011):

- in the first phase of stand development (pruning or qualifying phase) trees are selected by natural processes (breakdown 
into social classes and natural pruning);

- at the end of the qualifying phase, a small number (50-150 crop trees per hectare) of dominant, well-shaped, vigorous and healthy crop trees, evenly distributed, are selected;

- a crown thinning around crop trees is carried out to eliminate direct competitors and free up their crown, while the dominated layer is preserved to protect the soil and reduce the sprouting of new epicormic branches from the stem of crop trees;

- thinning is repeated every 4-8 years to stimulate crown-free growth and maintain a high and constant $\mathrm{DBH}$ increment until the merchantable market size $(\mathrm{DBH} 60 \mathrm{~cm}$ according to local market conditions) is achieved;

- thinning intensity is generally lower in terms of the number of felled trees $(\mathrm{N} \%)$, but is similar in terms of basal area (BA\%) compared with traditional thinning from below. The thinning cycle is more frequent, but decreased progressively with age.

\section{Experimental trials}

In our research, eight experimental plots were established in both areas: 5 plots in Amiata, in 2008, and 3 in Abetone, in 2011. In these plots the following silvicultural approaches were tested and compared:

- tree-oriented silviculture for around 100 crop trees (TS);
- traditional stand silviculture (SS);

- Control plot, unmanaged (C).

In the TS experimental plot about 100 dominant crop trees were selected, and crown thinning was carried out to make their crowns completely isolated and free from the competition of surrounding trees. Tree competitors around crop trees were removed, and a buffer space of 2-3 m (crown release - dètourage) was created to allow the free development of the crown. The remaining stand was preserved, and just a few trees were felled to allow logging operations. Crop trees were selected according to tree vigor, stem features, crown shape, lack of disease symptoms and spatial distribution. In the SS plot traditional thinning from below was carried out, removing mainly dominated and intermediate trees (Table 1)

In the control plot (C) no silvicultural intervention was carried out.

\section{Data collection, monitoring and analysis}

Stand level

In all experimental plots, periodic inventories were carried out, in correspondence of the thinning (2008, 2011 and 2018 in Amiata; 2011 and 2016 in Abetone), using a $5 \mathrm{~cm} \mathrm{DBH}$ threshold. Specific composition, diameter at breast height (DBH), social rank and a sample of 70 tree height $(\mathrm{H})$ per plot were measured. For each plot, the following stand parameters were calculated before (BT) and after thinning (AT):

Table 1 Main site characteristic and silvicultural treatment applied in the selected plots.

\begin{tabular}{|c|c|c|c|c|c|c|c|c|}
\hline Plot & $\begin{array}{l}\text { Silvicultural } \\
\text { treatment }\end{array}$ & $\begin{array}{c}\text { Surface } \\
\qquad\left(\mathrm{m}^{2}\right)\end{array}$ & $\begin{array}{c}\text { Age of } 1^{\text {st }} \\
\text { thinning } \\
\text { (years) }\end{array}$ & Aspect & Slope (\%) & $\begin{array}{l}\text { Altitude } \\
\text { (m a.s.l.) }\end{array}$ & $\begin{array}{c}1^{\text {st }} \\
\text { inventory } \\
\text { (years) }\end{array}$ & $\begin{array}{c}\text { N of } \\
\text { thinning }\end{array}$ \\
\hline AM1 & TS & 2000 & 45 & $\mathrm{NE}$ & 14 & 1415 & 2008 & 3 \\
\hline AM1 & SS & 2000 & 45 & NE & 14 & 1415 & 2008 & 2 \\
\hline AM2 & TS & 4900 & 50 & NW & 20 & 1315 & 2008 & 3 \\
\hline AM2 & SS & 4900 & 50 & NW & 20 & 1310 & 2008 & 2 \\
\hline AM2 & $\mathrm{C}$ & 1400 & 50 & NW & 20 & 1320 & 2008 & - \\
\hline $\mathrm{AB}$ & TS & 2800 & 48 & NE & 39 & 1240 & 2011 & 2 \\
\hline $\mathrm{AB}$ & SS & 2800 & 48 & $\mathrm{~N}$ & 38 & 1230 & 2011 & 1 \\
\hline $\mathrm{AB}$ & $\mathrm{C}$ & 1200 & 48 & NE & 20 & 1250 & 2011 & -- \\
\hline
\end{tabular}


site quality (through the dominant height), stand density (number of trees), productivity (basal area and volume), species composition (number of species, Shannon index - Shannon 1948), importance value for the dominant component (average of relative stem density and relative basal area of trees in the dominant layer Chapman et al. 2006).

Differences among tree distributions per diameter classes in each protocol (AM1 and AM2 in Amiata and $\mathrm{AB}$ in Abetone) were verified using the Kruskall-Wallis test, a non-parametric method for testing whether two or more independent samples of equal or different sample sizes originated from the same population.

Thinning type was assessed as a function of removal intensity (percentage of removed stems $\mathrm{N} \%$, percentage of removed basal area $\mathrm{BA} \%$, percentage of removed volume $\mathrm{V} \%$ ) and the ratio of removal intensity to $\mathrm{BA} \%$ and to $\mathrm{N} \%$ (TT ratio - Kerr \& Haufe 2011). This index defines the type of thinning accounting whereby values higher than 1.1 highlight thinning where dominant trees are being removed (selective thinning, thinning from above, crown thinning), while values lower than 0.9 define thinning where dominated trees are being removed.

Differences among silvicultural options and areas were assessed at stand level by comparing the differences in basal area (BA), volume (V) and their increment through inventories using Gurnaud's control method (in Mariotti et al. 2017):

$$
I=\frac{V 2-V 1+V h}{t 2-t 1}
$$

where V1 and V2 are the volumes at survey 1 and 2 respectively, and $\mathrm{Vh}$ is the harvested wood during the period t2-t1, calculating the corresponding growth rate (Gr \% year ${ }^{-1}$ ) according to the following equation:

$$
G r=\frac{I}{V 1}
$$

Differences in forest structure at stand level were analyzed by transects, located inside the plots, of $600 \mathrm{~m}^{2}(20 \times 30 \mathrm{~m})$ using a structural index both at horizontal and vertical level. Forest structure is both a product and driver of ecosystem processes and biological diversity. It is a result of management, disturbances and dynamics, but also has an important ecological role in ecosystem functioning, forest diversity and environmental value (Pommerenning 2006, Pretzsch 2009). Two indexes of structural diversity were selected to analyze and compare the effects of silviculture on stand structure. This investigation was carried out in the plots previously unmanaged ( 3 in Abetone $\mathrm{AB}$ and 2 in Amiata AM1), not considering the 3 plots previously thinned in Monte Amiata.

Among the vertical diversity indexes, we used the Vertical Evenness ( $V E$, Neumann and Starlinger 2001) index, calculated by splitting tree population into three height layers $(0-1 / 3$, $1 / 3-2 / 3,2 / 3-1$ of dominant height), and counting in the formula the number of trees within each layer:

$$
V E=\sum s_{i} \cdot p_{i} \cdot \frac{\ln \left(p_{i}\right)}{\ln \left(s_{i}\right)}
$$

where $s=$ number of height classes, $p_{i}=n_{i} / N$ with ni the number of trees in each height class and $\mathrm{N}$ the total number of trees. The index is a descriptor of tree layering, and it can range from 0 (one-layered stand) to 1 (multi-layered stand).

Among the horizontal diversity indexes, we used the Cox index (CI), quantifying clumping by the ratio between variance and the number of trees in equal sized sub-plots (Neumann and Starlinger, 2001). A variance to mean ratio of 1 indicates a random distribution, values less than 1 even distribution and values greater than 1 an increasingly clustered distribution. To understand whether different social classes exhibit different behaviors, the Cox index was also calculated considering only dominant trees.

Tree level

During the inventories carried out before and after thinnings (3 in Amiata 2008, 2011, 
2018 and 2 in Abetone 2011, 2016), additional periodic measurements were made on the crop trees of TS in order to allow a comparison of different silvicultural options. An equivalent number of crop trees were also selected in $\mathrm{SS}$ and $\mathrm{C}$ plots. For each crop tree, several additional parameters were recorded: diameter $(\mathrm{DBH})$, total height $(\mathrm{H})$, crown insertion (Hins), crown dimension (Dcr) and stem quality according to the 4 classes used for valuable broadleaved tree species (according to CEN standard, Nosenzo et al. 2012). Crop trees' DBH was measured annually at the end of the growing season.

In order to evaluate the impact of different silvicultural approaches on stem stability, the $\mathrm{H} / \mathrm{D}$ and $\mathrm{Dcr} / \mathrm{H}$ ratios of the crop trees were used as monitoring parameters, calculated at the beginning and at the end of the monitoring period.

In addition, the damage to crop trees caused by thinning or logging operations were recorded.

Differences among thinning options were assessed at crop tree level by comparing the $\mathrm{DBH}$ current annual increment (CAI), periodical $\mathrm{DBH}$ increment (PI), crown dimension (Dcr) by the analysis of variance (ANOVA), and the post-hoc HSD Tukey test, after verifying the normality distribution of the data (Kolmogorov-Smirnov and Lilliefors tests). Differences in stem quality class distribution were also evaluated using the $x^{2}$ Tukey test. All the analyses were performed using the software Statistica 7.1 (StatSoft USA).

\section{Results}

\section{Stand characteristics before thinning}

Before thinning, the Kruskal-Wallis test showed that no significant differences in the $\mathrm{DBH}$ distribution were recorded among the plots in each sites $(p=0.63$ in $A B, p=0.75$ in $\mathrm{AM} 1, \mathrm{p}=0.79$ in AM2).

The two sites at Monte Amiata (AM1 and AM2) showed differences in stand density and productivity due to past treatments (Table 2). In AM1 the absence of management has resulted in a very large number of trees (more than 4,000 trees ha $^{-1}$ in AM1 and less than half that number in AM2), and higher values for basal area and volume. At the same time, the impact of thinning carried out in AM2, before the commencement of research activity, is evident in the higher values of DBH and dominant diameter and in the importance value recorded for dominant component (0.51-0.58 in AM2 and $0.39-0.42$ in AM1). Tree biodiversity is very low at both sites, only one other tree species (Prunus avium L.) was recorded in one plot.

At the Abetone site, plots were more homogeneous (Table 3), beech was the

Table 2 Beech stands in Amiata and Abetone. Mensurational parameters, tree diversity and beech importance values in the study areas before thinning occurrence: (TS) tree oriented silviculture, (SS) stand silviculture, (C) control.

\begin{tabular}{llcccccccc}
\hline \multirow{2}{*}{ Plot } & & AM1 & AM1 & AM2 & AM2 & AM2 & AB & AB & AB \\
& & TS & SS & TS & SS & C & TS & SS & C \\
\hline Year of 1 $1^{\text {st thinning }}$ & -- & 2008 & 2008 & 2008 & 2008 & 2008 & 2011 & 2011 & 2011 \\
Number of trees & $\mathrm{n} \mathrm{ha}^{-1}$ & 4200 & 4095 & 1469 & 1069 & 1679 & 2493 & 2421 & 2500 \\
Dominant heigh & $\mathrm{m}$ & 20.7 & 20.1 & 21.6 & 22.3 & 21.4 & 21.4 & 22.3 & 19.1 \\
DBH $_{\mathrm{g}}$ & $\mathrm{cm}$ & 11.6 & 11.2 & 16.6 & 20.3 & 16.0 & 11.8 & 12.8 & 11.7 \\
$\mathrm{DBH}_{\mathrm{D}}$ & $\mathrm{cm}$ & 22.2 & 24.1 & 27.3 & 30.6 & 25.9 & 27.4 & 26.9 & 24.7 \\
Basal area & $\mathrm{m}^{2} \mathrm{ha}^{-1}$ & 44.32 & 41.66 & 31.78 & 34.52 & 33.68 & 27.18 & 31.29 & 26.65 \\
Volume & $\mathrm{m}^{3} \mathrm{ha}^{-1}$ & 419.5 & 391.8 & 340.6 & 386.1 & 355.9 & 262.3 & 337.7 & 253.6 \\
Tree diversity & Shannon index $_{\text {Number of species }}$ & 0.00 & 0.00 & 0.00 & 0.02 & 0.00 & 0.08 & 0.27 & 0.30 \\
Importance value & Dominant trees \% & 0.42 & 0.39 & 0.51 & 0.52 & 0.58 & 0.30 & 0.27 & 0.40 \\
\hline
\end{tabular}


Table 3 Beech stands in Amiata and Abetone. Mensurational parameters, tree diversity and importance value of the dominant trees in the study areas, at the last inventory, after silvicultural management: (TS) tree oriented silviculture, (SS) stand silviculture, (C) control.

\begin{tabular}{|c|c|c|c|c|c|c|c|c|c|}
\hline \multirow{2}{*}{\multicolumn{2}{|c|}{ Plot }} & AM1 & AM1 & AM2 & AM2 & AM2 & AB & AB & AB \\
\hline & & TS & SS & TS & SS & C & TS & SS & C \\
\hline Age & years & 55 & 55 & 58 & 58 & 58 & 53 & 53 & 53 \\
\hline Number of trees & $\mathrm{n} \mathrm{ha}^{-1}$ & 2605 & 975 & 755 & 414 & 1671 & 2225 & 1061 & 2767 \\
\hline Dominant heigh & $\mathrm{m}$ & 23.4 & 22.9 & 25.1 & 25.4 & 24.2 & 24.0 & 24.1 & 21.0 \\
\hline $\mathrm{DBH}_{\alpha}$ & $\mathrm{cm}$ & 12.3 & 18.6 & 19.7 & 27.7 & 17.8 & 10.8 & 18.1 & 12.3 \\
\hline $\mathrm{DBH}_{\mathrm{D}}^{\mathrm{g}}$ & $\mathrm{cm}$ & 27.2 & 26.2 & 33.9 & 34.4 & 30.0 & 28.5 & 29.1 & 27.5 \\
\hline Basal area & $\mathrm{m}^{2} \mathrm{ha}^{-1}$ & 30.81 & 26.38 & 23.00 & 24.91 & 41.76 & 20.22 & 27.21 & 32.84 \\
\hline Volume & $\mathrm{m}^{3} \mathrm{ha}^{-1}$ & 298.2 & 274.5 & 283.3 & 325.4 & 487.7 & 216.9 & 328.1 & 320.5 \\
\hline Tree diversity & Shannon index & 0.00 & 0.00 & 0.00 & 0.03 & 0.00 & 0.06 & 0.38 & 0.26 \\
\hline Number of species & $\mathrm{n}$ & 1 & 1 & 1 & 2 & 1 & 4 & 6 & 3 \\
\hline Importance value & Dominant trees $\%$ & 0.33 & 0.71 & 0.55 & 0.92 & 0.55 & 0.20 & 0.39 & 0.39 \\
\hline
\end{tabular}

dominant species, but was associated with a larger number of other sporadic trees, such as silver fir (Abies alba Mill), golden rain (Laburnum anagyroides Medik.), sycamore (Acer pseudoplatanus L.), rowan (Sorbus aucuparia L.), larch (Larix decidua Mill.). The importance values for dominant trees were similar to those recorded at the AM1 site (0.27-0.41).

\section{Thinning management}

At all sites thinning carried out for the two silvicultural options (TS and SS) differed in terms of frequency, intensity and social rank of the harvested trees (Figure 1).

In TS silvicultural treatment thinning was more frequent, with a lower intensity and a higher amount of removed dominant trees compared with SS treatment. Crown thinning (TS options) carried out around the crop trees to keep the crown of selected trees free to grow, was repeated after 3 and 7 years in Amiata and after 5 years in Abetone. The first thinning phase reduced stem density by $19 \%$ in Monte Amiata and $14 \%$ in Abetone AB TS. The second thinning was less intensive at the Abetone site (11\% of stem density) and AM1 site (13\%), but higher in AM2 (26\%). Finally, the third thinning phase carried out at Amiata showed a lower intensity of removed stems (11\% in AM1 and 12\% in AM2). In SS treatment only one thinning intervention was carried out at Abetone, whilst at Monte Amiata a thinning was repeated after 10 years.

Thinning caused a significant reduction in stem density in all plots: $55 \%, 30 \%$ and $58 \%$ respectively in $\mathrm{AM} 1, \mathrm{AM} 2$ and $\mathrm{AB}$ during the first thinning; $38 \%$ and $43 \%$ in AM1 and AM2 in the second thinning.
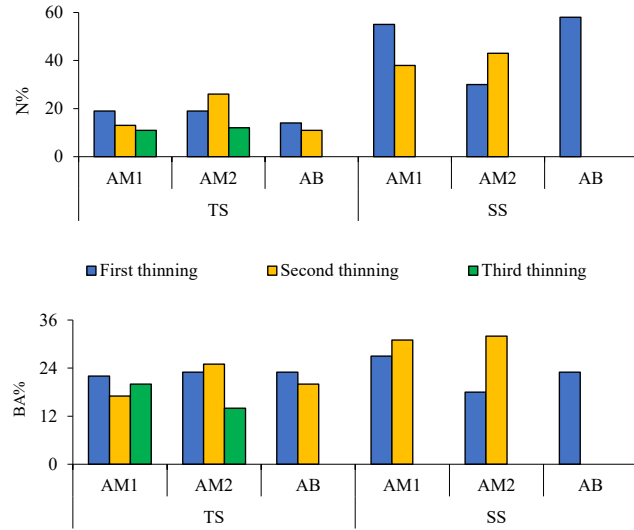

$\square$ First thinning $\quad$ 口Second thinning $\quad$ QThird thinning

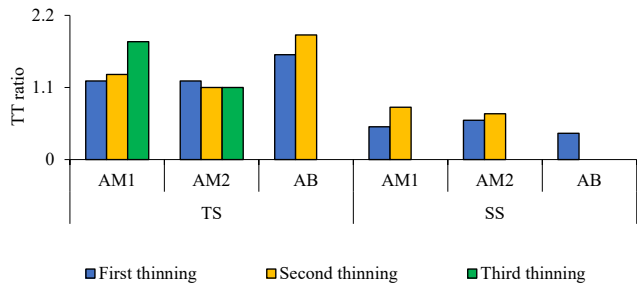

Figure 1 Thinning intensity (N\% and $\mathrm{BA} \%$ ) and thinning type (TT ratio) in the different treatments (TS, SS) in Amiata (AM1 and AM2) and Abetone (AB) plots. 
Considering the basal area parameter, the two silvicultural approaches proved to be similar in terms of $\mathrm{BA} \%$ reduction. At Monte Amiata, the TS option reduced BA by $17-22 \%$ in AM1 and $14-25 \%$ in AM2, while the SS option reduced BA by $27-31 \%$ in AM1 and $18-32 \%$ in AM2. At Abetone thinning intensity reduced BA by $20-23 \%$ for TS and by $23 \%$ for SS.

Differences in thinning were also well described by the TT ratio. Values higher than 1.1 were always obtained for the TS silvicultural option, while values $\leq 0.8$ were obtained for SS options in both areas (Figure 1).

\section{Stand characteristics after silvicultural management}

At the Monte Amiata site, after 10 years of silvicultural management (three thinnings in TS and two thinnings in SS), the KruskalWallis test showed significant differences in both sites $(p=0.04$ in AM1 and $p=0.01$ in AM2). Significant differences were recorded between the two thinning methods (TS and SS) at both sites; at the AM2 site the C plot was different to SS treatment, but not to TS treatment.

At the Abetone site the length of monitoring was only 5 years, with two thinnings (for TS) and one thinning (for SS) carried out. The Kruskal-Wallis test, for all diameter classes, showed no significant differences $(p=0.92)$ among the three methods. On the other hand, frequency distributions for the smaller diameter classes (up to $12 \mathrm{~cm}$ ) showed significant differences $(\mathrm{p}<0.01)$, between SS and the other methods.

The number of trees (Table 3 ) recorded in the last inventory had fallen in all thinned plots as a function of past management (one thinning from below was carried out in AM2 before the commencement of monitoring), number of thinnings (2-3 at Amiata and 1-2 at Abetone) and thinning type (TS or SS).

Tree density varied from 2,605 (TS) to 975 (SS) trees per hectare in AM1, from 1,671 (C) to 755 (TS) and 414 (SS) trees per hectare in
AM2, from 2,767 (C), to 2,225 (TS), to 1,061 (SS) trees per hectare in AB.

The basal area values were more homogeneous and lower in thinned plots (26.4$30.8 \mathrm{~m}^{2} \mathrm{ha}^{-1}$ in AM1, 23.0-24.9 $\mathrm{m}^{2} \mathrm{ha}^{-1}$ in AM2, 20.2-27.2 $\mathrm{m}^{2} \mathrm{ha}^{-1}$ in $\left.\mathrm{AB}\right)$ than in the control plot $\left(41.8 \mathrm{~m}^{2} \mathrm{ha}^{-1}\right.$ in AM2 and $32.8 \mathrm{~m} 2$ ha-1 in $\mathrm{AB})$. The mean diameter values were higher for the SS approach (18.6 cm in AM1, $27.7 \mathrm{~cm}$ in $\mathrm{AM} 2$ and $18.1 \mathrm{~cm}$ in $\mathrm{AB}$ ) compared to the TS option (12.3 cm in AM1, $19.7 \mathrm{~cm}$ in AM2 and $10.8 \mathrm{~cm}$ in $\mathrm{AB}$ ), although no differences were recorded for the dominant diameter. The diversity indices did not change after thinning, while the importance value for dominant trees was influenced by the type of thinning: in SS the dominant component was higher, and increased in relation to the first inventory; in TS the values were lower than for the previous inventory; in the control plot the index did not show significant changes.

\section{Growth at stand level}

The total annual volume increment between different inventories ( $\mathrm{Gr} \%$ ) and corresponding growth rate (I) showed up similar values between the different silvicultural options, but was slightly higher for the TS approach (Table 4). At the Amiata site total annual volume increments, calculated from the 1 st to the 3rd inventories (2008-2018), reached higher values in AM2 (from 13.2 to $14.5 \mathrm{~m}^{3} \mathrm{ha}^{-1} \mathrm{yr}^{-1}$ ) than AM1 (from 9.3 to $11.8 \mathrm{~m}^{3} \mathrm{ha}^{-1} \mathrm{yr}^{-1}$ ). The corresponding growth rate Gr varied from $2.4 \%$ in AM1 SS to $4.3 \%$ in AM2 TS. At Abetone the total annual increment, calculated from the $1 \mathrm{st}$ to the 2nd inventories (2006-2016), reached values from 10.6 (SS) to 14.6 (TS) $\mathrm{m}^{3} \mathrm{ha}^{-1} \mathrm{yr}^{-1}$, with a corresponding growth rate going from $3.1 \%$ to $5.6 \%$.

\section{Stand structures}

Structural diversity indices (Figure 2) showed multi-layered stands and a clustered distribution of trees in both areas. At Abetone higher vertical index values were recorded for the control plot 
Table 4 Harvested volume (V), total annual increment calculated by Gurnaud control method (I) and corresponding growth rates (Gr) before thinning (BT) and after thinning (AT).

\section{Harvested volume}

\begin{tabular}{|c|c|c|c|c|c|c|c|c|}
\hline Plot / treatment & V1-1 ${ }^{\text {st }}$ IV, BT & $1^{\text {st }} \mathrm{Th}$ & $2^{\text {nd }} T h$ & $3^{\text {rd }} \mathrm{Th}$ & V2-last IV, AT & Total Vh & I $\mathbf{m}^{3} \mathbf{h a}^{-1} \mathbf{y r}^{-1}$ & Gr \% \\
\hline AM1 TS & 419.5 & 91.7 & 63.5 & 84.2 & 298.2 & 239.4 & 11.8 & 2.8 \\
\hline AM1 SS & 391.8 & 93.6 & -- & 117.0 & 274.5 & 210.6 & 9.3 & 2.4 \\
\hline AM2 TS & 340.6 & 78.8 & 78.3 & 45.3 & 283.3 & 202.4 & 14.5 & 4.3 \\
\hline AM2 SS & 386.1 & 63.0 & -- & 139.9 & 325.4 & 202.9 & 14.2 & 3.7 \\
\hline $\mathrm{AM} 2 \mathrm{C}$ & 355.9 & -- & -- & -- & 487.7 & -- & 13.2 & 3.7 \\
\hline AB TS & 262.3 & 62.6 & 55.7 & -- & 216.9 & 118.3 & 14.6 & 5.6 \\
\hline AB SS & 337.7 & 62.5 & -- & -- & 328.1 & 62.5 & 10.6 & 3.1 \\
\hline $\mathrm{AB} C$ & 253.6 & -- & -- & -- & 320.5 & -- & 13.4 & 5.3 \\
\hline
\end{tabular}

Note: Iv: inventory; Th: thinning; Vh: harvested volume.

(0.94), and lower (0.89) for the SS approach. At Amiata the vertical structure was also more articulated in different layers in the plot thinned using the tree-oriented silviculture (0.72) compared with traditional thinning (0.69).

Cox index values were higher than 1 in all areas (cluster distribution), except for Monte Amiata, managed according to the traditional silviculture system, showing an even distribution $(\mathrm{SS}=0.33)$. The analysis of dominant layer horizontal diversity showed a more even tree distribution in all plots. A clustered distribution was preserved only for TS at Amiata (1.45).

\section{Growth at crop tree level}

Amiata

The effects of different thinning options caused significant differences on crop trees in terms of $\mathrm{DBH}$, periodical increment of diameter and crown diameter (Figure 3 and Figure 5). In particular, in 2019 in AM1 crop trees reached a mean DBH of $26.4 \mathrm{~cm}$ and $21.8 \mathrm{~cm}$ respectively for TS and SS while, in AM2, crop tree DBH in thinned plots reached $32.8 \mathrm{~cm}$ and $32.1 \mathrm{~cm}$, for TS and SS respectively. These values were significantly higher compared with $26.1 \mathrm{~cm}$ measured in the $\mathrm{C}$ plot in 2019 (Figure 3a). The effect of thinning on diameter growth is more evident analizing the periodical increment (PI) calculated for the period 2008-2019 in Amiata. The PI of the crop trees for TS are significant superior (6.3 and $7.8 \mathrm{~cm}$ rispecciveli for AM1 and AM2) to the other silvicultural options in all the two protocols (Figure 5). The effect of different thinning options is even more evident analyzing the crown diameter in 2019 at the end of the monitoring period: in AM1 the Dcr of the crop trees reached $5.6 \mathrm{~m}$ in TS and 4.1 $\mathrm{m}$ in SS, while in AM2 the Dcr reached $7.4 \mathrm{~m}$, $5.7 \mathrm{~m}$ and $4.7 \mathrm{~m}$ respectively for TS, SS and C (Figure 3c).

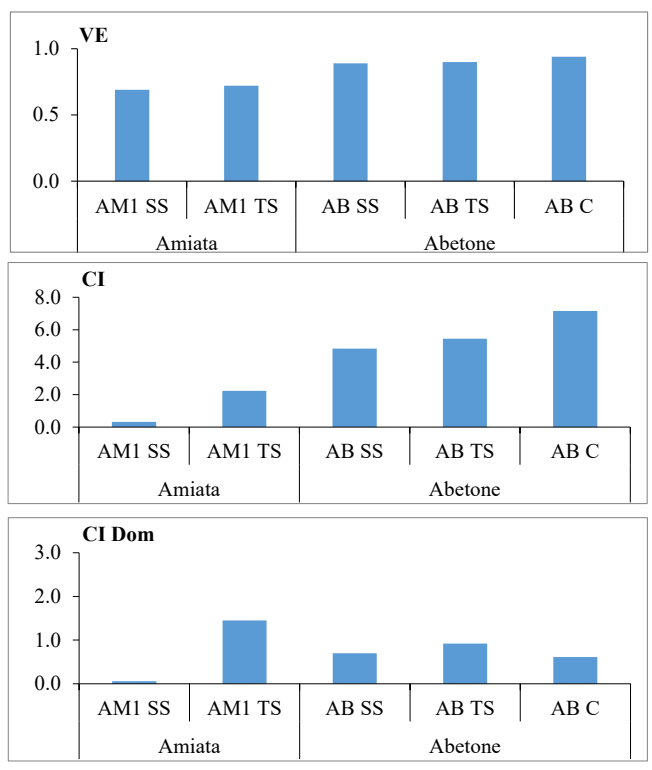

Figure 2 Indexes of structure diversity $(\mathrm{VE}=$ vertical index, $\mathrm{CI}=\mathrm{Cox}$ index of horizontal structure, CI Dom $=$ Cox index of horizontal structure of the dominant layer) in the different thesis (SS, TS, C) in Monte Amiata and Abetone plots, at the last inventory, after the silvicultural treatment. 
No significant differences were observed for height values in AM1, while in AM2 differences seen during the first inventory were maintained in the last inventory (Figure $3 b$ ).

The monitoring of CAI of diameter showed a significant growth increment for the TS treatment (Figure 3d). In particular, DBH CAI trends showed a superior reaction of the crop trees under the TS option compared to the traditional SS, but larger inter-annual variations. The crop trees selected in the AM1 area had a lower growth rate in 2008 compared to those selected in AM2, and showed a slower reaction to different thinning methods.

\section{Abetone}

At the Abetone site the effects of thinning options are less evident and not signficant than at Amiata. In 2019, the mean DBH value of crop trees in TS was greater $(28.7 \mathrm{~cm})$ than in $\mathrm{SS}(27.1 \mathrm{~cm})$ and control plots $(24.9 \mathrm{~cm})$ but not significant (Figure 4a). In Abetone the superior diameter growth in TS is more evident and significant considering the periodical increment (PI) calculated for the period 20112016 (Figure 5). After 5 years, PI of the crop trees reached $5.1 \mathrm{~cm}$ in TS, while values of 3.1 and $3.6 \mathrm{~cm}$ were found rispectivelly for
SS and C. There were significant differences only for height values (Figure 4b) both in 2011 and 2019. In particular, the height of AB SS and $\mathrm{AB}$ TS reached 24.3 and 23.6 compared to 21.8 measured for AB C at the end of 2019 . Significant differences were found in Dcr: the crown diameter reached $6.6 \mathrm{~m}$ for the TS option but only 5.7 and $4.4 \mathrm{~m}$ for the SS and C options in 2019 (Figure 4c). Also, at the Abetone site the analysis of DBH CAI trends showed a superior reaction of crop trees under the TS options compared to traditional SS (Figure 4d).

\section{Tree stability, stem quality and damage}

Interesting differences were found in the $\mathrm{H} /$ $\mathrm{DBH}$ ratio. Before thinning (2008 in AM1 and AM2 and 2011 in $\mathrm{AB}$ ), there were no significant differences among the plots of all three experimental sites. At the end of the monitoring period (2019), there was a reduction in the $\mathrm{H} / \mathrm{DBH}$ ratio in all the plots under tree-oriented silviculture, as well as an increase in tree stability. On the other hand, in the plots under traditional stand silviculture the $\mathrm{H} / \mathrm{DBH}$ ratio slightly rose (in $\mathrm{AM} 2$ and $\mathrm{AB}$ ) or remained stable (in AM1), while in the control plots there was a general increase in this ratio

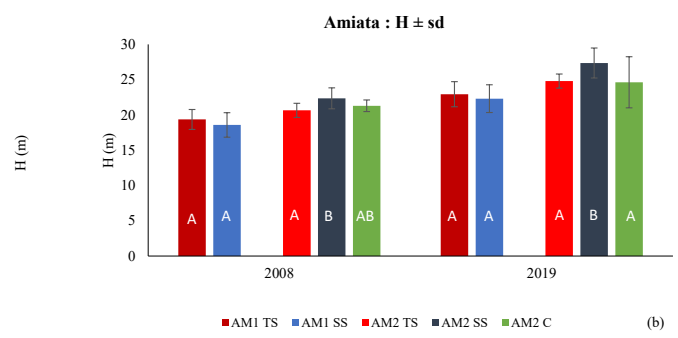

Amiata : DBH CAI \pm se

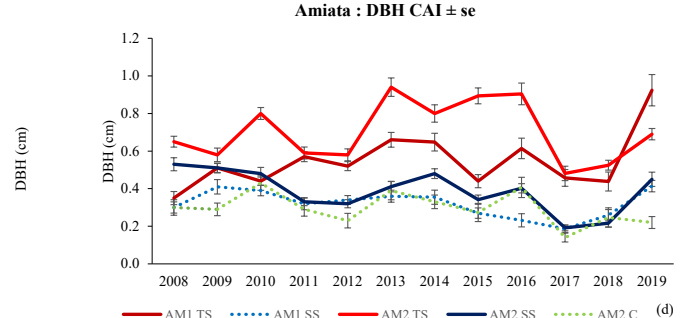

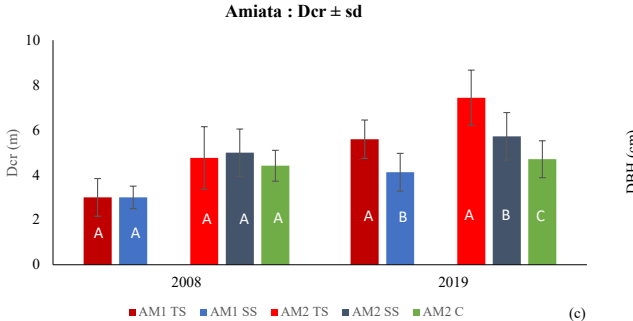

Figure 3 Main characteristics of the crop trees per silvicultural options in the two area of Monte Amiata. Letters indicate the differences among thesis (HSD test). 

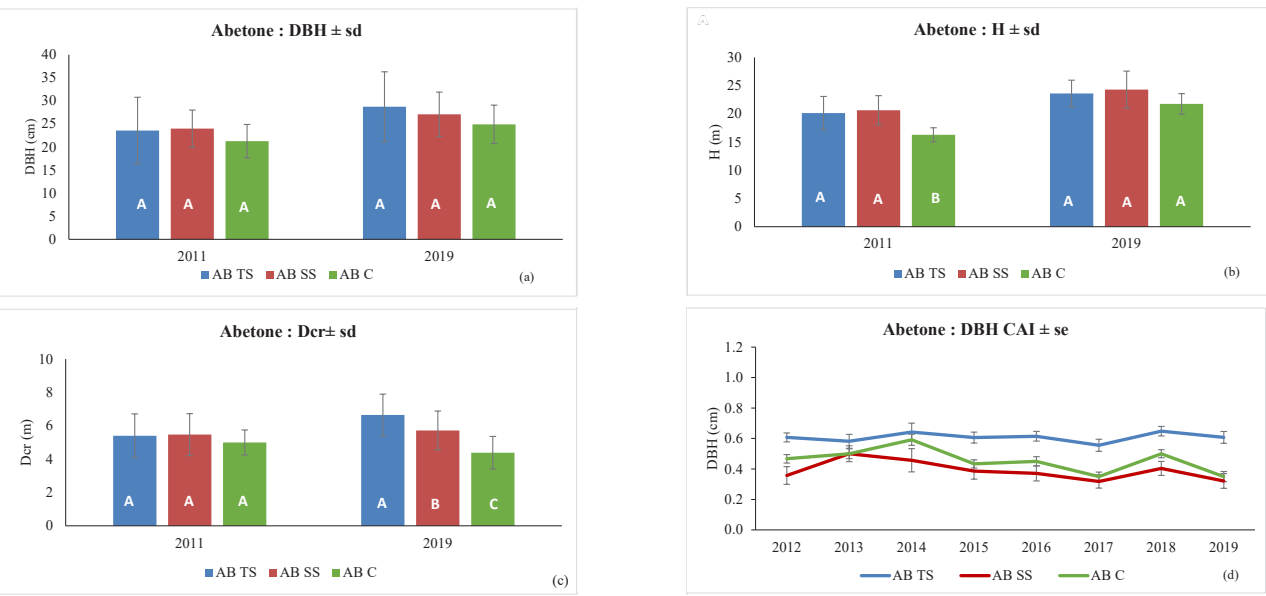

Figure 4 Principal characteristics of the crop trees per silvicultural options in the two area of the Abetone. Letter indicate differences among thesis (HSD test).
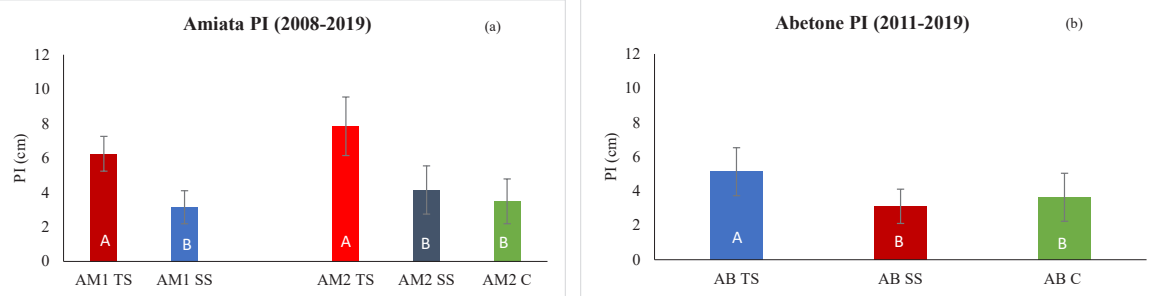

Figure 5 Periodical increments (PI) in the plots of Monte Amiata (AM; 2008-2019) and Abetone (AB; 2011-2019).

(Table 5). The HSD test showed significant differences among treatments in AM1 and in AM2, while no differences were observed in $\mathrm{AB}$.

Growth conditions were also analyzed using another synthetic index $(\mathrm{Dcr} / \mathrm{H})$, correlating crown diameter to tree height. In the first inventory, this ratio was similar for each experimental protocol (AM1, AM2 and AB), and no differences were observed among silvicultural treatments. In 2019 significant differences were observed between the TS plots and the other two approaches (SS and C). A clear rise in this ratio, as well as an increase in stability and crown development, was observed in crop trees under tree-oriented options. This ratio varied slightly for the SS option, while there was a progressive fall in the $\mathrm{Dcr} / \mathrm{H}$ ratio for the crop trees of the control plots.

Stem quality classes of crop trees were evaluated at the beginning of research activity
(2008 in AM1 and AM2 and 2011 on AB) and in 2019. Stem quality distributions, dividing the stem quality classes of crop trees into two categories $(A+B$ suitable for industrial transformation veneering and saw timber and $\mathrm{B}+\mathrm{C}$ suitable only for firewood and biomass production), are shown in Table 6 .

At the beginning of the trial, the Tukey $x^{2}$ test showed significant differences only in AM1, where the quality of TS was better compared to the SS option. In the other two trials (AM2 and $\mathrm{AB}$ ), no differences were noted in stem quality distribution. In 2019 significant differences in stem quality distribution was noted only in $\mathrm{AB}$. Generally, for the TS options, the stem quality of crop trees was higher compared with stem quality observed in crop trees selected in the stand silviculture and control plots, but these differences were not evident with the Tukey $x^{2}$ test. 
Table 5 Indexes of tree stability.

\begin{tabular}{|c|c|c|c|c|c|c|c|c|}
\hline \multicolumn{5}{|c|}{$2008 / 2011$} & \multicolumn{4}{|c|}{2019} \\
\hline Plot / treatment & H/DBH & HSD & Dcr/H & HSD & H/DBH & HSD & Dcr/H & HSD \\
\hline AM1 TS & $100 \pm 14$ & $\mathrm{~A}$ & $0.16 \pm 0.05$ & $\mathrm{~A}$ & $88 \pm 11$ & $\mathrm{~A}$ & $0.24 \pm 0.04$ & $\mathrm{~A}$ \\
\hline AM1 SS & $102 \pm 11$ & A & $0.16 \pm 0.04$ & A & $102 \pm 13$ & B & $0.19 \pm 0.04$ & B \\
\hline AM2 TS & $88 \pm 15$ & A & $0.23 \pm 0.06$ & A & $79 \pm 12$ & A & $0.29 \pm 0.04$ & A \\
\hline AM2 SS & $83 \pm 10$ & $\mathrm{AB}$ & $0.22 \pm 0.04$ & A & $87 \pm 11$ & $\mathrm{~B}$ & $0.21 \pm 0.04$ & $\mathrm{~B}$ \\
\hline $\mathrm{AM} 2 \mathrm{C}$ & $97 \pm 14$ & B & $0.21 \pm 0.04$ & A & $98 \pm 7$ & $\mathrm{C}$ & $0.19 \pm 0.03$ & $\mathrm{~B}$ \\
\hline $\mathrm{AB} T S$ & $89 \pm 16$ & $\mathrm{~A}$ & $0.27 \pm 0.06$ & A & $85 \pm 14$ & A & $0.28 \pm 0.05$ & $\mathrm{~B}$ \\
\hline AB SS & $87 \pm 10$ & A & $0.27 \pm 0.06$ & A & $91 \pm 14$ & A & $0.24 \pm 0.05$ & A \\
\hline $\mathrm{ABC}$ & $78 \pm 10$ & A & $0.31 \pm 0.04$ & A & $87 \pm 12$ & A & $0.20 \pm 0.04$ & A \\
\hline
\end{tabular}

Note: $\mathrm{H} / \mathrm{DBH}$ and $\mathrm{Dcr} / \mathrm{H}$ (where $\mathrm{H}=$ total height, $\mathrm{DBH}=$ diameter at breast height, $\mathrm{Dcr}=$ crown diameter) calculated for the crop trees in both areas and silvicultural approach. Mean values, standard deviation and significance HSD test are reported at the beginning and the end of monitoring period.

Table 6 Stem quality classes distribution per plot at the beginning and the end of monitoring period.

\begin{tabular}{|c|c|c|c|c|c|c|c|c|}
\hline \multicolumn{5}{|c|}{2008 / 2011} & \multicolumn{4}{|c|}{2019} \\
\hline Plot / treatment & $\mathbf{A}+\mathbf{B}$ & C+D & Total & A+B $\%$ & $\mathbf{A}+\mathbf{B}$ & C+D & Total & $\mathrm{A}+\mathrm{B} \%$ \\
\hline AM1 TS & 13 & 7 & 20 & 65 & 17 & 4 & 21 & 81 \\
\hline AM1 SS & 7 & 15 & 22 & 32 & 15 & 7 & 22 & 68 \\
\hline \multirow[t]{2}{*}{ Total } & 20 & 22 & 42 & 48 & 32 & 11 & 43 & 74 \\
\hline & & $x^{2}$ & 4.624 & $\mathrm{p}<0.05$ & & $x^{2}$ & 0.920 & n.s. \\
\hline AM2 TS & 19 & 30 & 49 & 39 & 29 & 17 & 46 & 63 \\
\hline AM2 SS & 22 & 26 & 48 & 46 & 24 & 24 & 48 & 50 \\
\hline $\mathrm{AM} 2 \mathrm{C}$ & 8 & 7 & 15 & 53 & 7 & 7 & 14 & 50 \\
\hline \multirow[t]{2}{*}{ Total } & 49 & 63 & 112 & 44 & 60 & 48 & 108 & 56 \\
\hline & & $x^{2}$ & 1.137 & n.s. & & $x^{2}$ & 1.820 & n.s. \\
\hline AB TS & 24 & 3 & 27 & 89 & 25 & 2 & 27 & 93 \\
\hline AB SS & 23 & 5 & 28 & 82 & 17 & 11 & 28 & 61 \\
\hline $\mathrm{AB} C$ & 7 & 5 & 12 & 58 & 7 & 5 & 12 & 58 \\
\hline \multirow[t]{2}{*}{ Total } & 54 & 13 & 67 & 81 & 49 & 18 & 67 & 73 \\
\hline & & $x^{2}$ & 5.033 & n.s. & & $x^{2}$ & 8.739 & $\mathrm{p}<0.05$ \\
\hline
\end{tabular}

Note: The Tukey $x^{2}$ test was applied grouping the stem classes in two categories: $\mathrm{A}+\mathrm{B}$ (industrial trasformation) and $\mathrm{C}+\mathrm{D}$ (firewood and biomass production).

The analysis of damage occurring to crop trees during thinning operations (felling and logging), showed that damage was mainly localized for the TS approach (10-15\% of crop trees), in particular on the stem of the tree. On the other hand, damage was absent (in AM1 and $\mathrm{AB}$ ) or limited (4\% in AM2) for the SS approach.

\section{Discussion}

The main effects of silviculture intervention were to modify stand structure, reduce stem density and competition processes. The effects depended on thinning type, length and number of treatments. In our experiments two different silvicultural approaches were tested:

- The stand silviculture (SS), easy to apply and tending to generate monolayer, pure and even-aged stands. The main effects were the simplification of stand structure, the widespread presence of trees in the dominant layer and the progressive death of light-demanding minority tree species. - The tree-oriented silviculture (TS), more difficult to apply, mainly in the pool stage, due to the selection of crop trees and logging difficulties for first thinnings. This approach helps to maintain a multilayered stand structure, and to preserve the presence of minority tree species. The TS approach makes it possible to adapt treatment to the biological needs of different tree species, and favors the conservation of light-demanding species, such as wild cherry and rowan (Pelleri et al. 2013, Schütz et al. 2016). 
Thinning intensity was not particularly different for the two approaches: for TS the basal area removed was 5-6 $\mathrm{m}^{2} \mathrm{ha}^{-1}(20-23 \%)$ in Abetone, and 4-10 $\mathrm{m}^{2} \mathrm{ha}^{-1}$ (17-25\%) in Amiata. For SS $7 \mathrm{~m}^{2} \mathrm{ha}^{-1}$ (23\%) in Abetone, and 6-12 $\mathrm{m}^{2} \mathrm{ha}^{-1}(18-32 \%)$ in Amiata were removed. Nevertheless, tree-oriented silviculture guaranteed larger-sized timber assortments of, better quality and easier market placement, as already found for chestnut coppices (Manetti et al. 2016) and black Pine stands (Marchi et al. 2018) under different thinning methods.

Quantities are rather low, but the presence of a good network of forest tracks makes such intervention economically sustainable (Pelleri et al. 2013). Slightly higher values were obtained in other experimental trials in Italy for chestnut coppices (Manetti et al. 2016) where, during the $1^{\text {st }}$ and the $2^{\text {nd }}$ thinnings, BA removed reached 8-10 $\mathrm{m}^{2} \mathrm{ha}^{-1}$ in Amiata and 4-13 $\mathrm{m}^{2} \mathrm{ha}^{-1}$ in the Colline Metallifere. Similar intensities were obtained for beech stands in Italy, with 26-32\% of BA removed (Mariotti et al. 2017) and in Slovenia, with $18-27 \%$ and $16-22 \%$ of BA removed under different selective thinning regimes (Boncina et al. 2007). Similar BA removal (5-10 $\left.\mathrm{m}^{2} \mathrm{ha}^{-1}\right)$ was observed in regular beech high forest stands in France managed under a TS approach (Bastien et al. 2005).

At stand level, the application of TS caused, according to the Gurnaud method, higher total volume increments compared with traditional SS both at the Abetone and Amiata plots. These values are higher than the indexes obtained by Mariotti et al. (2017) in beech stands converted to high forest, managed with two different thinning methods (selective and low). At Amiata total volume increments (I) from 9.3 to $14.5 \mathrm{~m}^{3} \mathrm{ha}^{-1} \mathrm{yr}^{-1}$ were observed, while at Abetone values from 10.6 to 14.6 $\mathrm{m}^{3} \mathrm{ha}^{-1} \mathrm{yr}^{-1}$ with growth rates $(\mathrm{G} \%)$ from 2.4 to $4.3 \%$ in Amiata and from 3.1 to $5.6 \%$ in Abetone were recorded. These higher volume increments derived from higher soil fertility and from higher volumes at the time of the first inventory. It is important to point out that when applying the TS option most of the volume increment is concentrated in a small number of crop trees, causing a higher increment in volume and value of the assortment produced by these trees, whereas for the other option (SS), the total increment is spread among all the stands, and mainly among dominant trees. The different length of treatment, and above all the number of thinning interventions, resulted in important structural differences following the application of the two approaches. At the Amiata site, after 11 years and 2-3 thinnings, the TS approach produced a higher stand density and therefore lower DBH values; a more articulated vertical structure and consequently lesser importance of the dominant component; a higher growth rate of crop trees due to the isolation of the crowns. At the Abetone site, the trend was similar, but a shorter monitoring period (5 years) and fewer thinnings (1-2), did not make it possible to see more significant differences among the approaches.

Spatial distribution was also influenced by the monitoring period and number of thinnings. At the Amiata site trees were evenly distributed for the SS approach and clumping distributed for TS. On the other hand, at the Abetone site, all plots had a clumping distribution. The differences between approaches emerged when the social layers were analyzed separately. Trees in the dominant layer showed a regular or random distribution for all plots, except for TS in Amiata.

Other authors too found a clear difference between the spatial distribution of overstorey and understorey both in old-growth Norway Spruce, Douglas-fir and beech forests (Svensson and Jeglum 2001, Franklin et al. 2002, Boncina et al. 2007, Becagli et al. 2016). Generally, trees in the understorey were clumped because they can develop mainly in the spaces between overstorey trees, and groups of small diameter shade-tolerant trees can grow under an overstorey of large wellspaced trees. 
Similar to the control plots, the TS approach maintains a high stem density and complex stand structure, but a lower competition level and higher growth rate, as revealed by other authors regarding beech forests (Boncina et al. 2007). On the other hand, the SS approach differentiates plots in terms of both structure and stand growth. This simplification is easier to manage but less functional from an ecological point of view.

Growth analysis at crop tree level pointed out a higher growth in $\mathrm{DBH}$ and crown dimension of the crop trees selected in the TS plots, while the progressive reduction in height growth of the crop trees was due to the lower competition levels and to the effects of crown isolation. These parameters have influenced the individual stability of crop trees, as shown by the stability index. This index went down over time in the crop trees selected in the TS plots, while an increase was observed in the crop trees selected in the SS plots. Similar results were observed in beech forests managed with selective thinning compared with forests managed with thinning from below (Mariotti et al. 2017) and in black Pine artificial forests (Marchi et al. 2018).

The higher crown development and lower height growth also caused an increase in the $\mathrm{Dcr} / \mathrm{H}$ ratio in the crop trees under the TS option, showing a reduction in competition levels tested by this simple index in oak stands (Lemaire 2010).

The DBH current increments for crop trees underlined significant differences between the TS option and the other two approaches (SS and C). Current increment values were always greater in the plot managed under TS, while the other two approaches showed comparable and lower DBH current increments.

The application of TS helped to keep the crown of the crop trees isolated and free to grow over time without the competition of the surrounding trees. In our case, this made it possible to obtain a higher growth of the crown diameter, about $24 \mathrm{~cm} \mathrm{yr}^{-1}$ at Amiata and 18 $\mathrm{cm} \mathrm{yr}^{-1}$ at Abetone, a value three times higher than the growth obtained under SS. Higher crown increments of the crop trees, from 36 to $50 \mathrm{~cm} \mathrm{yr}^{-1}$, were obtained in younger beech stands (12-14 $\mathrm{m}$ of dominant height) managed under TS and subjected to different intensities of crown release (De Potter et al. 2012).

Overall, the application of TS enhances best trees, in terms of vigor and stem quality, stimulating their diameter growth and development of the crown. These factors help to improve crop tree stability by reducing the slenderness ratio and blocking the insertion of the crown, preventing its progressive rising due to the strong competition of surrounding trees. In this way, much of the growth of the stand is concentrated on a limited number of dominant trees, the best being able to provide the most valuable assortments as per market demand. With this silvicultural approach, a broad and valuable assortment will be obtained in a shorter time compared with the traditional SS, with undoubted advantages from an economic and environmental point of view.

\section{Conclusion}

Compared with non-management, both applied silvicultural methods had positive effects on tree stability, stand efficiency and tree growth. These benefits can help to counteract the negative effects of climate change - such as wind storms, fire and pathogen attack - and increase the environmental and landscape value of stands in areas having a high tourist vocation, such as those we have analyzed.

Nevertheless, tree-oriented silviculture has proven to be the management type that best meets the multifunctionality requirements of the nowadays forests. Tree-oriented silviculture indeed is able to combine the productive function with the protection and preservation aspects, granting not only economic but also ecological, environmental and landscape benefits. These functions can be further enhanced when the regeneration phase is long term, and when management 
helps to preserve stands having an irregular structure. On the other hand, while traditional stand silviculture has some environmental advantages, economic aspects are given the absolute priority.

The main strengths of tree-oriented silviculture as seen in our research are:

- producing high-value assortments with a longer Life Cycle Assessment;

- developing economic aspects, especially a higher quality of assortments obtained with intermediate thinning; enhancing the sporadic tree species of particular ecological, environmental and economic interest;

- preserving articulated, complex and differentiated stand structures, even in small areas;

- increasing and preserving biodiversity, even despite the small number of minority tree species;

- increasing the mechanical stability of trees;

- allowing higher carbon sequestration by concentrating most of the volume in a few large trees; overcoming the idea of rotation periods and introducing the concept of a longer regeneration period.

The main weaknesses can be highlighted as follows:

- a need for more knowledge, care and complexity in forest planning; training of technical and operating personnel;

- care needed during felling and logging operations, since damage caused to a single crop tree can thwart the management's efforts;

- type and size of the forest property: this innovative system may not be understood by small private owners, who make up the majority of owners;

- trends of wood markets and local supply chains.

In traditional stand silviculture, the main strengths are:

- an increase in the quantity of the final product, with a standard quality;

- simple management, both in the planning phase and for felling operations;

- adaptability to the needs of private property.

The main weaknesses revealed by our study are:

- a low degree of structural complexity;

- scarce attention paid to sporadic tree species.

In conclusion, only a knowledge of the main strengths and weaknesses of the two silvicultural approaches can help to choose the management type that best suits the economic, social and environmental characteristics of a specific territory.

In our study, a definitive evaluation of the two silvicultural approaches can only be obtained at the end of the rotation period, by evaluating production aspects, other ecosystem services and difficulties during the regeneration phase.

\section{Funding}

The work was financially supported by the European Project LIFE PProSpoT and by the Regional Project SELVARBO.

\section{Declaration on conflicts of interest}

The authors declare that they have no conflict of interest.

\section{References}

Armand G. (Coord.), 2002. Le hêtre autrement. Institut pour le Dèveloppement Forestier, Paris, 262 p.

Bastien Y., 1997. Pour l'éducation de Hêtre en fustaie claire et mélangée. Revue Forestière Française 49 (1): 49-68.

Bastien Y., Hein S., Chavanne A., 2005. Sylviculture du hêtre: contraintes, enjeux, orientation de gestion. Revue Forestière Française 2: 111-122. https://doi. org/10.4267/2042/5030

Bastien Y., Wilhelm G.J., 2000. Une sylviculture d'arbres pour produire des gros bois de qualité. Revue Forestière Française 5: 407-424. https://doi. org/10.4267/2042/5376

Becagli C., Puletti N., Chiavetta U., Cantiani P., Salvati L., Fabbio G., 2016. Early impact of alternative thinning approaches on structure diversity and complexity 
at stand level in two beech forests in Italy. Annals of Selvicultural Research 37 (1): 55-63. http://dx.doi. org/10.12899/asr-802

Bončìna A., Kadunc A., Robic D., 2007. Effects of selective thinning on growth and development of beech (Fagus sylvatica L.) forest stands in south-eastern Slovenia. Annals of Forest Science 64: 47-57. https:// doi.org/10.1051/forest:2006087

Brang P., Spathelf P., Bo Larsen J., Bauhus J., Bončìna A., Chauvin C., Drőssler L., Garcìa-Güemes C., Heiri C., Kerr G., Lexer MJ., Mason B., Mohren F., Mühlethaler U., Nocentini S., Svoboda M., 2014. Suitability of closeto-nature silviculture for adapting temperate European forests to climate change. Forestry 87: 492-503. http:// doi.org/10.1093/forestry/cpu018.

Brunet J., Fritz Ö., Richnau G., 2010. Biodiversity in European beech forests - a review with recommendations for sustainable forest management. Ecological Bulletins 53: 77-94

Ciancio O., Corona P., Lamonaca A., Portoghesi L., Travaglini D., 2006. Conversion of clearcut beech coppices into high forests with continuous cover: a case study in central Italy. Forest Ecology and Management 224: 235-240. https://doi.org/10.1016/j. foreco.2005.12.045

Chapman R.A., Heitzman E., Shelton M.G., 2006. Longterm changes in forest structure and species composition of an upland oak forest in Arkansas. Forest Ecology and Management 236 (1): 85-92. https://doi.org/10.1016/j. foreco.2006.08.341

Coppini M., Hermanin L., 2007. Restoration of selective beech coppices: A case study in the Apennines (Italy). Forest Ecology and Management 249: 18-27. https:// doi.org/10.1016/j.foreco.2007.04.035

Cullotta S., La Placa G., Maetzke F.G., 2016. Effects of traditional coppice practices and microsite conditions on tree health in a European beech forest at its southernmost range. iForest 9: 673-681. https://doi. org/10.3832/ifor1603-008

De Potter B., Perin J., Claessen H., 2012. Détourage d'abres-objectif: Enseignements des dispositifs istallés en Walloine après six annes. Forêt Wallonne 119: 43-54.

De Saint-Vaulry M., 1969. A la recherche d'une autre silviculture: l'individualisation précoce des arbres d'avenir. Revue Forestière Française XXI (2): 83-100.

Ducellier U., 1930. La Forêt de Bellôme et une nouvelle méthode d'enclaircie. Revue des Eaux et des Forêts 68 (4): 263-278.

Franklin J.F., Spies T.A., Van Pelt R., Carey A.B., Thornburgh D.A., Berg D.R., Lindenmayer D.B., Harmon M.E., Keeton W.S., Shaw D.C., Bible K., Chen J., 2002. Disturbances and structural development of natural forest ecosystems with silvicultural implications, using Douglas-Fir forests as an example. Forest Ecology and Management 155: 399-423. https:// doi.org/10.1016/S0378-1127(01)00575-8

Hahn K., Fanta J., 2001. Contemporary beech forest management in Europe. University of Copenhagen.
NAT-MAN Working Report 1.

Jobling J., Pearce M.L., 1977. Free growth of oak. Forestry Commission Forest Record No 113. HMSO, London, $16 \mathrm{p}$.

Kerr G., Haufe J., 2011. Thinning practice. A silvicultural guide. Edinburgh: Forestry Commission, $54 \mathrm{p}$.

Lemaire J., 2010. Le chêne autrement: Produire du chêne de qualité en moins de 100 ans en futaie régulière. Guide technique. Institut pour le Développement Forestier: Centre National de la Propriété Forestière, Paris.

Löf M., Brunet J., Filyushkina A., Lindbladh M., Skovsgaard J.P., Felton A., 2015. Management of oak forests: striking a balance between timber production, biodiversity and cultural services. International Journal of Biodiversity Science Ecosystem Services \& Management 12: 59-73. https://doi.org/10.1080/21513 732.2015.1120780

Manetti MC., Becagli C., Sansone D., Pelleri F., 2016. Single tree-oriented silviculture: a new approach for coppice stands. iForest 9: 791-800. https://doi. org/10.3832/ifor1827-009

Manetti MC., Becagli C., Bertini G., Cantiani P., Marchi M., Pelleri F., Sansone D., Fabbio G. 2020. The conversion into high forest of Turkey oak coppice stands: methods, silviculture and perspectives. iForest 13: 309-317. https://doi.org/10.3832/ifor3483-013

Marchi M., Paletto A., Cantiani P., Bianchetto E., De Meo I., 2018. Comparing thinning system effects on ecosystem services provision in artificial black pine (Pinus nigra J. F. Arnold) forests. Forests 9: 188. https://doi.org/10.3390/19040188

Mairota P., Manetti MC., Amorini E., Pelleri F., Terradura M., Frattegiani M., Savini P., Grohmann F., Mori P., Terzuolo P., Piussi P., 2016 - Opportunities for coppice management at the landscape level: the Italian experience. iForest 9: 775-782. https://doi.org/10.3832/ ifor1865-009

Mariotti B., Alberti G., Maltoni A., Tani A., Piussi P., 2017. Beech coppice conversion to high forest: results from a 31-year experiment in Eastern Pre-Alps. Annals of Forest Science 74: 44-47. https://doi.org/10.1007/ s13595-017-0642-1

Mason B., Kerr G., Pommerening A., Edwards C., Hale S., Ireland D., Moore R., 2003. Continuous cover forestry in British conifer forests. Forest Research Annual Report and Accounts, $53 \mathrm{p}$.

Meyer P., Tabaku V., Von Lupke B., 2003. Structural characteristics of Albanian beech (Fagus sylvatica L.) virgin forests. Deductions for semi-natural forestry. Forstwissenschaftliches Centralblatt 122 (1): 47-58.

Michealis K.A., 1907. Wie bringt Durchforsten die grőssere Stärke und Wertznahme des Holzes. Verlag von J. Neumann-Neudamm, 43 p.

Möller C.M., 1931. Starke Durchforstung in Dänisher Beleuchtung. Zeitschrift für das Forst und Jagdwesen: 369-393.

Negro M., Vacchiano G., Berretti R., Chamberlain D.E., Palestrini C., Motta R., Rolandoegro A., 2014. Effects 
of forest management on ground beetle diversity in alpine beech (Fagus sylvatica L.) stands. Forest Ecology and Management 328: 300-309. http://dx.doi. org/10.1016/j.foreco.2014.05.049

Neuman M., Starlinger P., 2001. The significance of different indices for stand structure and diversity in forest. Forest Ecology Management 145: 91-106. https://doi.org/10.1016/S0378-1127(00)00577-6

Nocentini S., 2009. Structure and management of beech (Fagus sylvatica L.) forests in Italy. iForest 2: 105-113. https://doi.org/10.3832/ifor0499-002

Nosenzo A., Boetto G., Berretti R., Travaglia P.M., 2012. Applicazione dell'indice di qualità su un campione di impianti di arboricoltura da legno del Piemonte. Sherwood, Foreste e Alberi Oggi 183: 21-25.

Pelleri F., Sansone D., Bianchetto E., Bidini C., Sichi A., 2013. Selvicoltura d'albero in fustaie di faggio: valorizzazione delle specie sporadiche e coltivazione della specie dominante. Sherwood Foreste e Alberi Oggi 190: 43-47.

Perin J., Claessens H., 2009. Considérations sur la désignation et le détourage en chênes et hêtres. Forêt Wallonne 98: 39-52.

Perkey A.W., Wilkins B.L., Smith C., 1994. Crop Trees Management in Eastern Hardwood. USDA Forest Service, Morgantown, NA-TP-19-93, $57 \mathrm{p}$.

Piussi P., Alberti G., 2015. Selvicoltura generale. Boschi, società e tecniche colturali. Compagnia delle Foreste, Arezzo, Italy, $432 \mathrm{p}$.

Pommerening A., 2006. Evaluating structural indices by reversing forest structural analysis. Forest Ecology and Management 224: 266-277. https://doi.org/10.1016/j. foreco.2005.12.039

Pretzsch H., 2009. Forest dynamics growth and yield: From measurement to model. Berlin: Springer Verlag, $664 \mathrm{p}$.

Sansone D., Bianchetto E., Bidini C., Ravagni S., Nitti D., Samola A., Pelleri F., 2012. Selvicoltura d'albero nei cedui giovani: interventi di valorizzazione delle specie sporadiche nell'ambito del Progetto LIFE+ PProSpoT. Sherwood, Foreste e Alberi Oggi 185: 5-10.

Schädelin W., 1942. Die Auslesedurchforstung als Erziehungsbetrieb höchster Wertleistung, Bern, 1942.

Schütz J.P., 1990. Sylviculture 1: principes d'éducation des forêts. Presses Polytechniques et Universitaires Romandes, $243 \mathrm{p}$.
Schütz J.P., Saniga M., Diaci J., Vrška T., 2016. Comparing close-to-nature silviculture with processes in pristine forests: lessons from Central Europe. Annals of Forest Science 73: 911-921. https://doi.org/10.1007/s13595016-0579-9

Shannon C. E., 1948. The mathematical theory of communication. University of Illinois Press, Urbana, IL, USA, pp. 29-125.

Spiecker H., 2006. Minority tree species: a challenge for a multi-purpose forestry. Diaci J. (Ed.), NatureBased Forestry in Central Europe. Alternatives to Industrial Forestry and Strict Preservation, University of Ljubljana 126: 47-59.

Svensson J.S., Jeglum J.K., 2001. Structure and dynamics of an undisturbed old-growth Norway spruce forest on the rising Bothnian coastline. Forest Ecology and Management 151: 67-79. https://doi.org/10.1016/ S0378-1127(00)00697-6

Tabacchi G., De Natale F., Di Cosmo L., Floris A., Gagliano G., Gasparini P., Salvadori I., Scrinzi G., Tosi V., 2007. IFNC Inventario Nazionale delle Foreste e dei Serbatoi Forestali di Carbonio. Seconda parte: le stime di superficie. MiPAF - Corpo Forestale dello Stato Ispettorato Generale, CRA - ISAFA, Trento. URL: http://www.infc.it

Von Teuffel K., Hein S., 2004. Sylviculture du Hêtre proche de la nature en Bade-Wurttemberg. Revue Forestière Française 56 (6): 519-528. https://doi. org/10.4267/2042/5118

Wilhelm G.J,, 2003. Qualification-grossissement: la stratégie sylvicole de Rhénanie-Palatinat. RDV, Office National des Forêt 1: 4-9.

Wilhelm G.J., Rieger H., 2017. Stratégie QD: une gestion de la forêt basée sur la qualité et les cycles naturels. CNPF et Forêt Wallonne asbl. Pris, 192 p.

Wolynski A., 2002a. Sul trattamento irregolare delle fustaie di faggio (parte prima). Sherwood, Foreste e Alberi Oggi 74: 9-14.

Wolynski A., 2002b. Sul trattamento irregolare delle fustaie di faggio (parte seconda). Sherwood, Foreste e Alberi Oggi 75: 5-13.

Wolynski A., Berretti R., Motta R., 2006. Selvicoltura multifunzionale orientata alla qualità. Caratterizzazione di una faggeta in provincia di Trento. Sherwood, Foreste e Alberi Oggi 118: 1-8. 
